\title{
Biochemical Parameters of Temporemandibular Joint Pain Dysfunction Syndrome
}

\author{
Sofi Chikobava, PhD Student \\ St. Michael Archangel Multi profile Clinical Hospital, \\ Department of Maxillofacial Surgery, Tbilisi, Georgia \\ Marine Nikolaishvili, Prof. and Head of Department \\ I. Beritashvili Center of Experimental Biomedicine, Tbilisi, Georgia \\ Mamuka Gogiberidze, Professor \\ St. Michael Archangel Multi Profile Clinical Hospital, \\ Department of Maxillofacial Surgery, Tbilisi, Georgia
}

Doi: 10.19044/esj.2019.v15n18p13～URL:http://dx.doi.org/10.19044/esj.2019.v15n18p13

\begin{abstract}
The complex approach to the treatment of patients with rheumatic diseases (RD) has been elaborated at the department. Considering the above, this paper focuses on studying the biochemical parameters of blood serum characterizing the body's response to pain and stress. This is achieved by examining the content of histamine and hormones (adrenaline, cortisol, TSH, total alkaline phosphatase) (Total ALP) in patients with pain dysfunction syndrome of the TMJ, taking into account changes in the blood biochemical composition ( $\mathrm{K}, \mathrm{Na}, \mathrm{Ca}, \mathrm{Mg}, \mathrm{Cl}$, protein, glucose, Vitamin $\mathrm{D}$, and adenosine triphosphate acid). Objective: To evaluate the efficiency of Biochemical Parameters of Temporemandibular Joint Pain Dysfunction Syndrome. Patients and Methods: The study of biochemical parameters of blood serum was held in patients with temporomandibular joint pain dysfunction syndrome. Biochemical studies were conducted in 61 patients with TMJ pain dysfunction syndrome at the age of 20 to 40 years (1st, main group) and in 10 healthy people of similar age who do not show any complaints characteristics of the studied pathology (2nd, control). Results and Discussion: There is a significant increase in the level of sodium and total protein, which has not been statistically confirmed. For vitamin D (total 40.98IU/ml) and alkaline phosphatase activity, there was a significant decrease in vitamin D in temporom and ibular disorder patients when compared to the controls $(\mathrm{P}=0.001)$. Also, there was a significant negative correlation between serum vitamin $\mathrm{D}$ activity with total alkaline phosphatase activity in temporomandibular disorder patients $(\mathrm{P}=0.001)$. In addition, there was a significant increase in serum total alkaline phosphatase as bone marker in
\end{abstract}


temporomandibular disorder patients which provides a more reliable and complete profile of inflammatory contributors to temporomandibular disorder. A tendency to decreasing in the content of calcium, total protein, and glucose in the blood serum were found. Thus, this indicates the activation of stress systems and the enhancement of protein catabolism. A significant increase in the content of ATP, histamine, adrenaline, and cortisol confirms the important role of psycho-emotional disorders in the pathogenesis of temporomandibular joint pain dysfunction syndrome.

Keywords: Temporomandibular joint pain dysfunction syndrome, Biochemical parameters of blood serum

\section{Introduction}

Diseases of the temporomandibular joint (TMJ) are actual problem of dentistry and 70-89\% of cases are not associated with inflammatory and dystrophic processes in the joint. However, they are caused by functional intra-articular disorders. A special place among such diseases is occupied by the syndrome of pain dysfunction of the temporomandibular joint (according to the international classification of dental diseases based on ICD-10, 1997). This is known in the literature as myofascial pain dysfunctional face syndrome, neuro-muscular syndrome, cranial-mandibular dysfunctional syndrome, occlusive articulation syndrome, etc. Such a variety in the designation of this pathology is apparently explained by the complexity of the anatomical structure and kinetics of this joint, and not by the ambiguous pathogenesis of the disease (Boonstra, 2011; Antico, 2012; Ahmed, 2015). The temporomandibular joint is a key element of the articulation system, which is formed by the bones of the middle zone, the joint itself, the upper and lower jaws, the hyoid bone and the teeth, and finally the muscles that determine the movements of the mandible. The complexity of the anatomical structure and kinetics of the temporomandibular joint, the dependence of the correct intra-articular relationships on the nature of the closure of the dentition, and the tone and function of the chewing muscles create the background that causes the greater frequency of diseases and the ambiguity of the pathogenesis of the syndrome of pain dysfunction of the TMJ (Aliko, 2011; Adegboye, 2013).

The proposed theories of the pathogenesis of the syndrome of pain dysfunction of the TMJ mainly compete with each other. Therefore, it reflects four (4) main aspects, apparently, depending on the medical specialty of researchers:

- The role of organic and functional changes in the temporomandibular joint;

- The role of changes in the state of the chewing muscles; 
- The role of psychological personality disorders;

- The role of occlusal disharmony.

In addition, a number of authors associate functional changes in the joint with instability of the cervical spine, cervical osteochondrosis, impaired biomechanics of the neck muscles, and shoulder girdle with injury. Currently, these are the recognized endocrine factors of the disease TMJ, in particular the dysfunction of the thyroid gland.

Meanwhile, the energy metabolism, the mechanical activity of the muscles, including chewing, the permeability of cell membranes, and the transmission of nerve impulses are the most important parts of biological processes that occur with the participation of electrolytes, in particular calcium, potassium, sodium, magnesium, chlorine. In addition, their content depends on the physiological state of the organism (Beto, 2015). There are few reports in the literature that calcium, potassium, iron, and zinc deficiency are characteristics of pain and this leads to an increase in myofascial trigger points, a decrease in calcium levels, and an increase in the concentration of thyroid-stimulating hormone in serum with myofascial pain. The absorption of sa great value has vitamin D. Calcium and vitamin D is required to improve and conserve healthy bones and teeth (Sipina, 2003; Vestegaard, 2003, Brini, 2013).

Pain, emotional stress, and tension cause the release of excess histamine, increased secretion of cortisol, and adrenaline which is involved in the regulation of vital body functions. It also plays a leading role in the pathogenesis of stress and disease states. We have not come across data on the study of their content in serum diseases of the TMJ, but we have taken into consideration the role of psychogenic factors in the pathogenesis of TMJ pain dysfunction syndrome - such studies are of interest (Chervotok, 2009; Leeuw, 2013).

Diagnosis of this pathology is difficult because of the variety of clinical symptoms. The main symptom that causes the patient to see a doctor is pain, which occurs in $67-90 \%$ of cases. The pain is mainly caused by muscle spasm (myogenic nature of pain) or injury of the soft tissue structures of the joint by the head of the mandibular condyle, which changed its position (arthrogenic nature of pain).

Characteristic are affective disorders of the depressive spectrum, articular noise - from 14 to $50 \%$ of cases, restriction of mouth opening, chin deviation when opening the mouth, and occlusive disorders (Marques, 2010; Kudryavtseva, 2010; Kim, 2012; Callhoff, 2015).

Considering the above, this paper focuses on studying the biochemical parameters of blood serum characterizing the body's response to pain and stress by examining the content of histamine and hormones (adrenaline, 
cortisol, TSH, total alkaline phosphatase (Total ALP) in patients with pain dysfunction syndrome of the TMJ, taking into account changes in the blood biochemical composition ( $\mathrm{K}, \mathrm{Na}, \mathrm{Ca}, \mathrm{Mg}, \mathrm{Cl}$, Vitamin $\mathrm{D}$, protein, glucose, and adenosine triphosphate acid).

Material and Methods: Biochemical studies were conducted in 61 patients with TMJ pain dysfunction syndrome aged from 20 to 40 (1st, main group) and in 20 healthy individuals of the same age with no complaints characteristic of the pathology (2nd, control group).

The serum levels of potassium, sodium, calcium, magnesium, and chlorine were determined on an AVL-988 electrolyte analyzer (Austria), an automated device with microprocessor control. The required amount of the test substance is 500ml. Unit of measure - mmol/1 (Brini, 2013; Beto, 2015).

The serum level of total protein and glucose was determined on "Quadro" - a biochemical analyzer (Italy) using diagnostic kits. The unit of measurement in determining total protein is $\mathrm{g} / \mathrm{l}$, glucose - mmol / 1 (Kim, 2012; Sipina, 2003).

To determine the level of adenosine triphosphate (ATP) in serum, a spectrophotometric method was used, based on the fact that the last two phosphoric acid residues in ATP, rich in energy, as well as the phosphate residue in creatine-phosphate are easily split off during short-term hydrolysis in an acidic medium. Unit of measurement - mcmol/1

The content in the serum, histamine, adrenaline, cortisol, TSH, total alkaline phosphatase, and Vitamin D was determined on an immunoassay analyzer "ELISA" kits. The unit of histamine is mcmol/l, adrenaline is mmol/1, Vitamin D IU/ml (Marques, 2010; Maruotti, 2010).

Results and Discussion: The results of biochemical studies of blood serum in patients with TMJ pain dysfunction syndrome and in control subjects are presented in Table 1.

Table 1. The results of biochemical studies of blood serum in patients with TMJ pain dysfunction syndrome and in control subjects

\begin{tabular}{|l|l|l|l|l|l|l|l|}
\hline $\begin{array}{l}\text { Research } \\
\text { groups }\end{array}$ & $\begin{array}{l}\mathrm{K}, \\
\mathrm{mmol} / \mathrm{l}\end{array}$ & $\begin{array}{l}\mathrm{Na}, \\
\mathrm{mmol} / \mathrm{l}\end{array}$ & $\begin{array}{l}\mathrm{Ca}, \\
\mathrm{mmol} / \mathrm{l}\end{array}$ & $\begin{array}{l}\mathrm{Mg}, \\
\mathrm{mmol} / \mathrm{l}\end{array}$ & $\begin{array}{l}\mathrm{Cl}, \\
\mathrm{mmol} / \mathrm{l}\end{array}$ & $\begin{array}{l}\text { Protein, } \\
\mathrm{g} / \mathrm{l}\end{array}$ & $\begin{array}{l}\text { Vitamin } \\
(\mathrm{IU} / \mathrm{ml})\end{array}$ \\
\hline 1 & 2 & 3 & 4 & 5 & 6 & 7 & $\mathrm{D}$ \\
\hline $\begin{array}{l}\text { 1st, main } \\
\text { group } \\
\mathrm{n}=31\end{array}$ & $\begin{array}{l}4,57 \pm 0,09 \\
\mathrm{p}>0,05\end{array}$ & $\begin{array}{l}145,47 \pm 1,14 \\
\mathrm{p}<0,05\end{array}$ & $\begin{array}{l}0,99 \pm 0,03 \\
\mathrm{p}>0,05\end{array}$ & $0,78 \pm 0,06$ & $\begin{array}{l}106,01 \pm 0,53 \\
\mathrm{p}>0,05\end{array}$ & $\begin{array}{l}75,82 \pm 1,38 \\
\mathrm{p}>0,05\end{array}$ & $\begin{array}{l}30.89 \pm 32.28 \\
\mathrm{p}<0,05\end{array}$ \\
$\begin{array}{l}\text { 2nd, } \\
\text { control } \\
\text { group } \\
\text { n=31 }\end{array}$ & $4,38 \pm 0,15$ & $134,9 \pm 2,37$ & $1,27 \pm 0,05$ & $0,77 \pm 0,06$ & $109,58 \pm 2,29$ & $77,76 \pm 2,54$ & $40.98 \pm 13.50$ \\
\hline
\end{tabular}




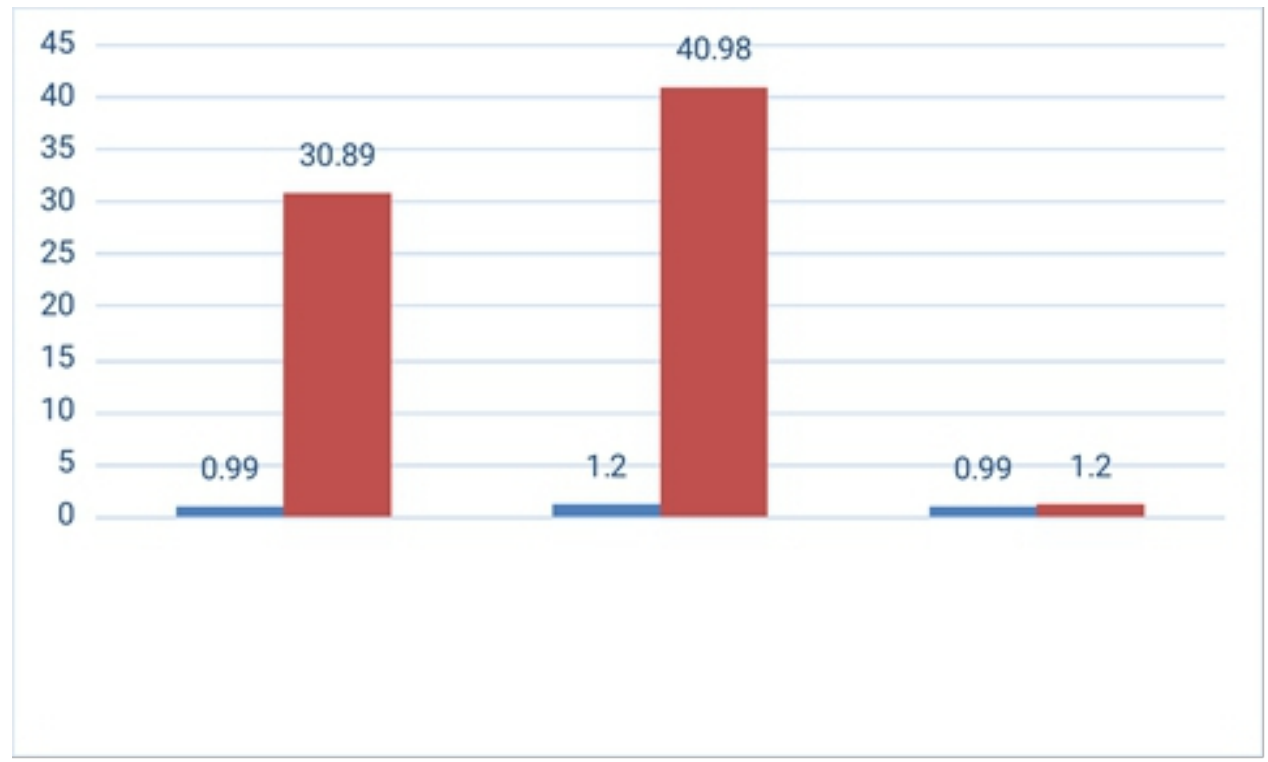

Figure 1. Correlations coefficient between serum vitamin $\mathrm{D}$ and $\mathrm{Ca}^{+2}$ levels in patients with TMJ pain dysfunction syndrome

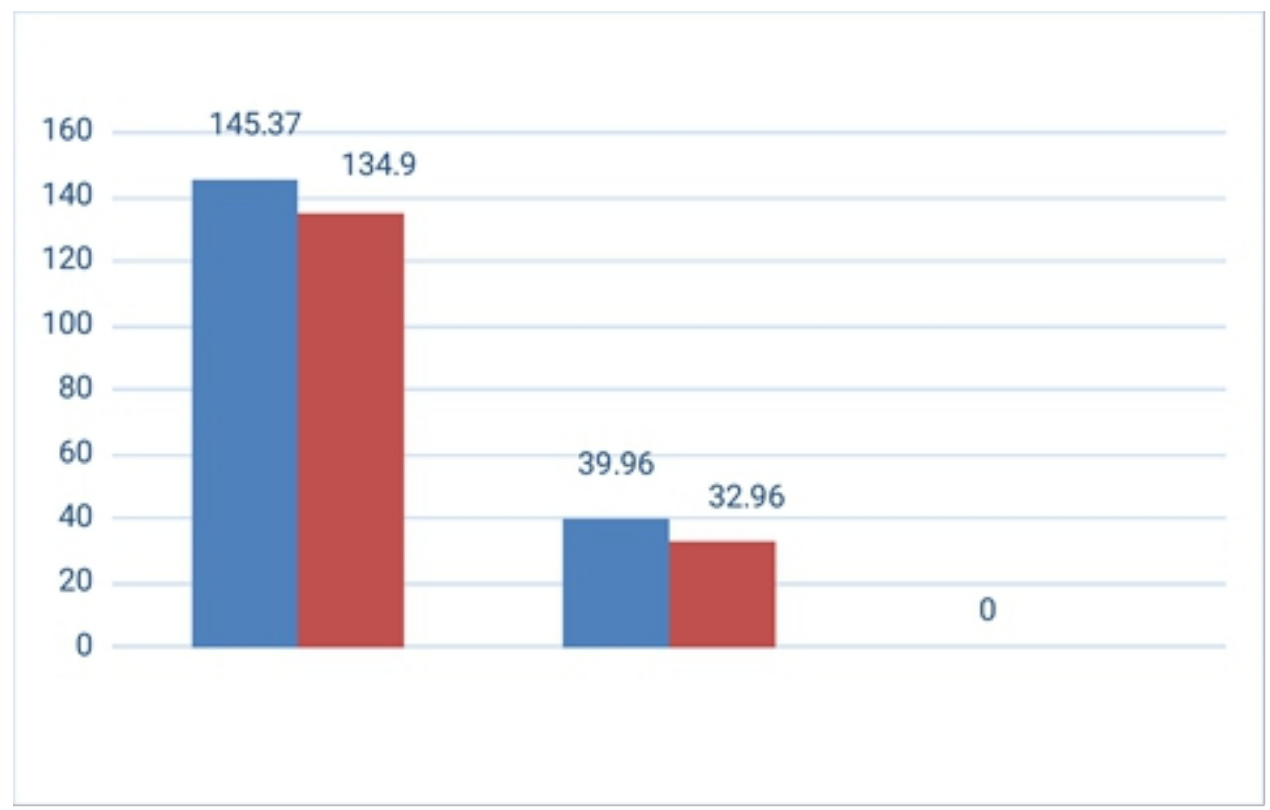

Figure 2.The results of biochemical studies $\mathrm{Na}$ and ATF of blood serum in patients with TMJ pain dysfunction syndrome

A comparative analysis of the content of electrolytes in the blood serum showed that patients with pain dysfunction syndrome of the TMJ showed a significant increase in sodium from $134.9 \pm 2.36$ to $145.47 \pm 1.14$ $\mathrm{mmol} / \mathrm{l}(\mathrm{P}<0.05)$. This is in the absence of reliable changes in the level of potassium $(4.38 \pm 0.15$ and $4.57 \pm 0.09 \mathrm{mmol} / \mathrm{l}$, respectively, $\mathrm{P}>0.05)$ 
compared with similar indicators in the control group, which indirectly indicates the activation of stress systems and stress damage to internal organs (Leeuw, 2013; Maruotti, 2010).

The serum calcium content in patients with TMJ pain dysfunction syndrome was $0.99 \pm 0.03 \mathrm{mmol} / \mathrm{l}$, which was $6 \%$ lower than that of healthy people in the control group $(1.2 \pm 0.05$; $\mathrm{P}>0.05)$. This is consistent with the literature data on a slight decrease in blood calcium inmyofascial face pain syndrome (Adegboye, 2013; Marques, 2010), muscle contractility, and the detected tendency which may indicate some disorders of neuromuscular transmission. The magnesium and chlorine content in both groups was the same and was within the physiological norm. In the glucose level, there is only a slight uptrend in the 1st main group. Vitamin D is required to control Ca+2 absorption and homeostasis. Low levels of vitamin D (30.89 \pm 32.28 and 40.98 \pm 13.50 ) have been concerned in a numeral of chronic diseases namely RD with TMJ pain dysfunction syndrome. Dietary $\mathrm{Ca}+2$ absorption is critical for $\mathrm{Ca}+2$ availability for bone mineralization, and vitamin $\mathrm{D}$ status is a significant parameter influencing intestinal $\mathrm{Ca}+2$ absorption. Current data (Grant, 2010; Maruotti, 2010), therefore, suggests that proper vitamin D intakes facilitate beneficial effects of higher $\mathrm{Ca}+2$ intakes, probably by improvement of $\mathrm{Ca}+2$ absorption. Vitamin D status is a significant parameter influencing intestinal $\mathrm{Ca}+2$ absorption. Sufficient $\mathrm{Ca}+2$ intake is essential for all people.

Vitamin $\mathrm{D}$ is required to control $\mathrm{Ca}+2$ absorption and homeostasis. From literature (Gelbard, 2017; Antico, 2012; Adegboye, 2013), it is known that higher intakes of $\mathrm{Ca}+2$, dairy-foods and vitamin $\mathrm{D}$ are inversely connected with caries and periodontitis. Dietary $\mathrm{Ca}+2$ absorption is critical for $\mathrm{Ca}+2$ availability for bone mineralization, and vitamin $\mathrm{D}$ status is a significant parameter influencing intestinal $\mathrm{Ca}+2$ absorption. Calcium and vitamin $\mathrm{D}$ is required to improve and conserve healthy bones and teeth.

Results and Discussion: The results of biochemical studies of blood serum in patients with TMJ pain dysfunction syndrome and in control subjects are presented in Table 2.

Table 2. The results of biochemical studies of blood serum in patients with TMJ pain dysfunction syndrome and in control subjects

\begin{tabular}{|l|l|l|l|l|l|l|l|}
\hline $\begin{array}{l}\text { Research } \\
\text { groups }\end{array}$ & $\begin{array}{l}\text { Total } \\
\text { protein }\end{array}$ & $\begin{array}{l}\text { Adenosine } \\
\text { triphosphate }\end{array}$ & Histamine & Adrenalin & Cortisol & $\begin{array}{l}\text { Tireotropgo } \\
\text { rmon, TTG }\end{array}$ & $\begin{array}{l}\text { Total } \\
\text { (U/L) }\end{array}$ \\
\hline $\begin{array}{l}\text { 1st, main } \\
\text { group } \mathrm{n}=31\end{array}$ & $\begin{array}{l}5,09 \pm 1,38 \\
\mathrm{p}>0,05\end{array}$ & $\begin{array}{l}39,96 \pm 2,0 \\
\mathrm{p}<0,05\end{array}$ & $\begin{array}{l}0,46 \pm 0,02 \\
\mathrm{p}<0,001\end{array}$ & $\begin{array}{l}0,93 \pm 0,04 \\
\mathrm{p}<0,001\end{array}$ & $\begin{array}{l}361,68 \pm 20,6 \\
\mathrm{p}<0,001\end{array}$ & $\begin{array}{l}1,93 \pm 0,11 \\
\mathrm{p}>0,05\end{array}$ & $\begin{array}{l}124.0 \pm 18.90 \\
\mathrm{p}<0,001\end{array}$ \\
$\begin{array}{l}\text { 2nd, } \\
\text { control } \\
\text { group n=31 }\end{array}$ & $5,03 \pm 0,25$ & $32,96 \pm 2,08$ & $0,31 \pm 0,04$ & $0,54 \pm 0,03$ & $239,3 \pm 18,05$ & $1,67 \pm 0,37$ & $133.42 \pm 26.50$ \\
\hline
\end{tabular}




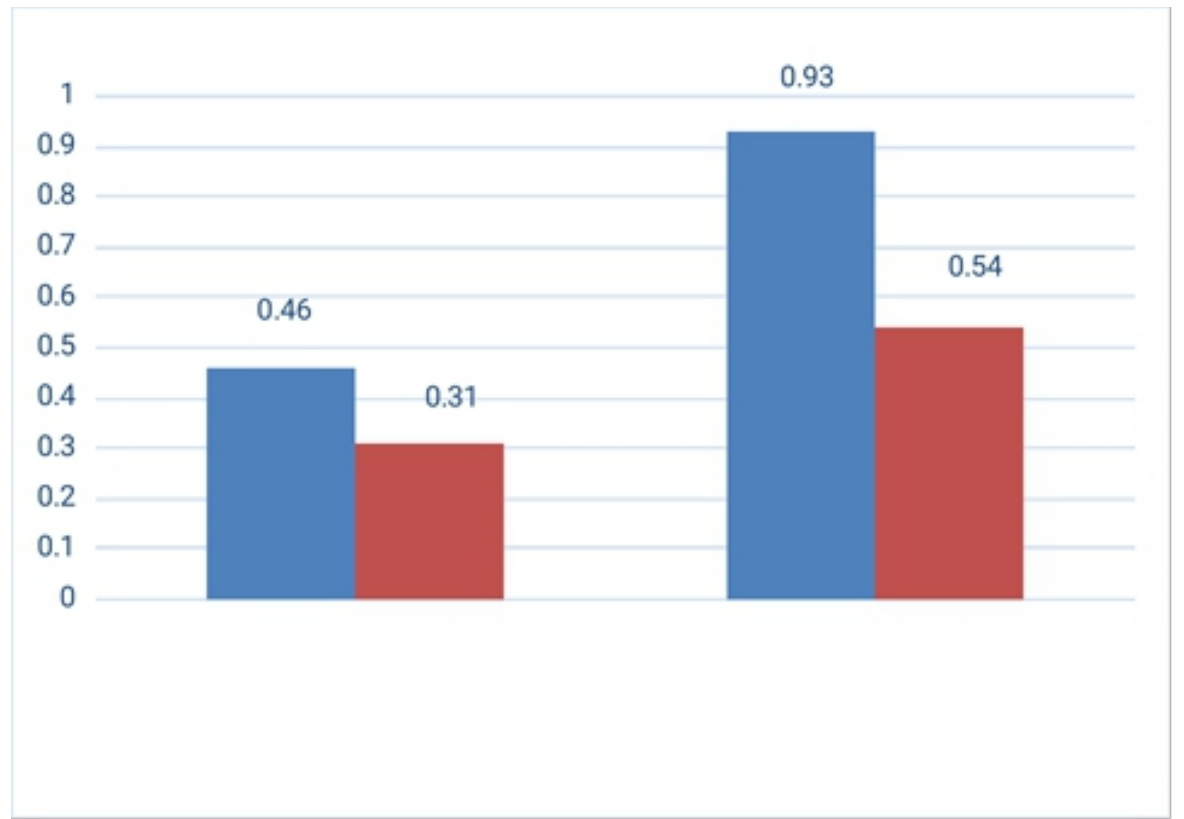

Figure 3.The results of biochemical studies on Histamin and Adrenalin of blood serum in patients with TMJ pain dysfunction syndrome

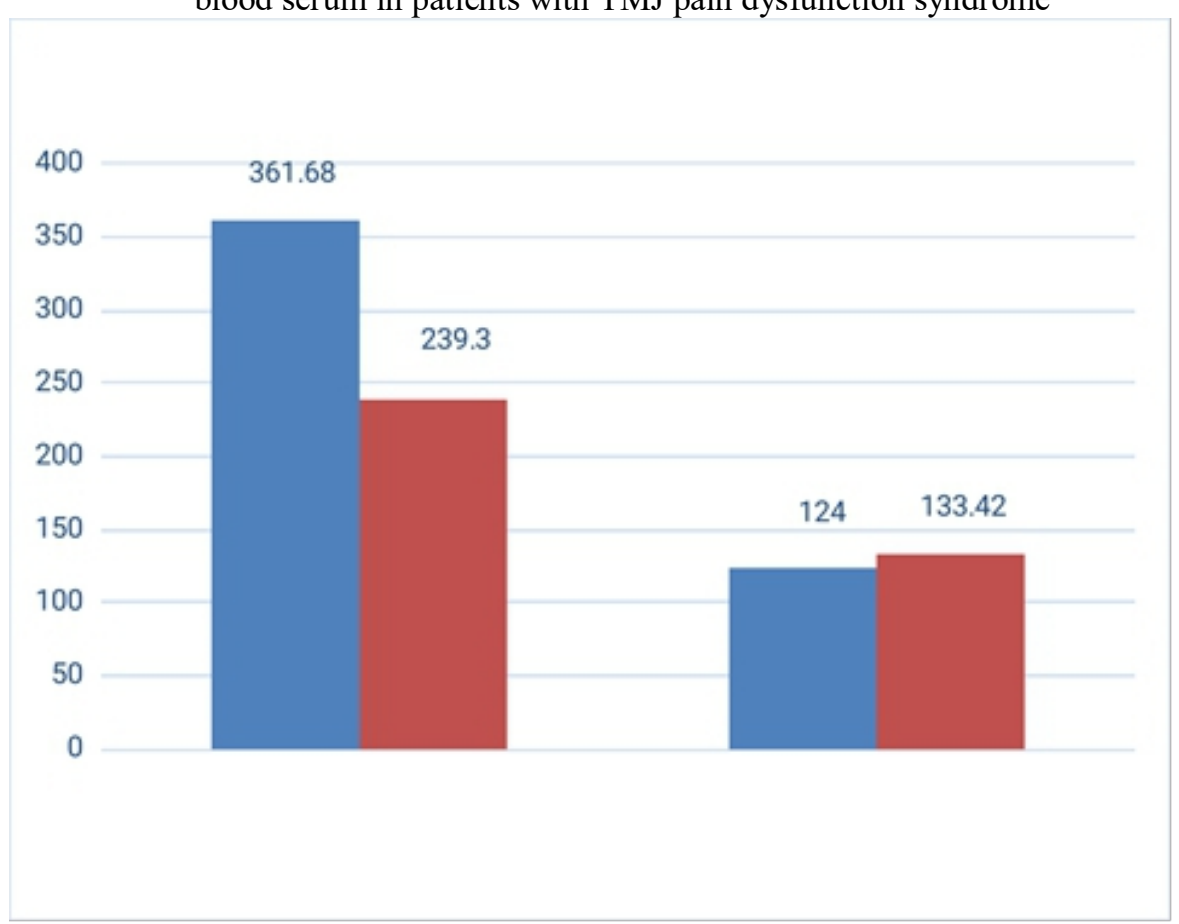

Figure 4. The results of biochemical studies on Histamin and Adrenalin of blood serum in patients with TMJ pain dysfunction syndrome

According to the revealed tendency to decrease in the amount of total protein (by $0.25 \%$; $\mathrm{P}>0.05$ ) in serum with TMJ pain dysfunction syndrome, 
it is possible to judge the restructuring of metabolic activity towards the enhancement of protein catabolism (Kumar, 2016; Wong, 2003).

The results of the study of the content of electrolytes, total protein, and glucose in the serum are consistent with the data of the authors who studied the changes in biochemical parameters in rats when modeling acute and chronic pain (Kumar, 2016; Kudryavtseva, 2010).

The level of adenosine triphosphate (ATP) in the serum of patients was significantly higher than in the control group (39.96 \pm 2.0 and $32.96 \pm 2.08$ $\mathrm{mmol} / \mathrm{l}, \mathrm{P}<0,05)$. ATP is known to be the main source of energy for muscle contraction (Callhoff, 2015). It controls the sodium-potassium pump, which, through the cell membrane, supports the $\mathrm{K}+$ and $\mathrm{Na}+$ gradients necessary for the excitation of muscle and nerve fibers (Leeuw, 2013; Wong, 2003). Consequently, an increase in ATP content indicates an increased muscle tone in these patients. However, for its provision more energy is needed and the source of which is ATP.

A comparative analysis of the content of histamine and hormones in the blood serum of the subjects showed a sharp increase in their pain in the TMJ pain dysfunction syndrome. Hence, in the 1st main group compared with the control, the content of histamine in the serum was higher by $51.75 \%(0.46$ \pm 0.02 and $0.31 \pm 0.04 \mathrm{mmol} / 1$, respectively, $\mathrm{P}<0.001)$. It is likely that an increase in histamine is responsible for the development of pain in this syndrome. The level of adrenaline increased by $76.9 \%(0.93 \pm 0.04$ and 0.54 $\pm 0.03 \mathrm{mmol} / \mathrm{l}$, respectively, $\mathrm{P}<0.001)$, cortisol by $51.4 \%(361.68 \pm 20,6$ and $239.3 \pm 18.05$, respectively, $\mathrm{P}<0.001$ ), which was a convincing evidence that the syndrome of pain dysfunction of the TMJ, accompanied by tension in the psycho-emotional sphere, is a typical adaptation syndrome with an increase in the production of stress hormones - adrenaline and corticosteroids.

In this study, patients ALP activity is higher relative to control which is in agreement with the study of Kumar et al. The role of ALP is implicated in osteoid formation and mineralization and expression of its isoform is in osteoblasts, leucocytes, breast, liver, kidney, and brain. The bone construction markers are measured in serum and about 1/2 of ALP in serum comes from bone. Increased ALP activity may be due to its leakage from injured or killed cells. Alkaline phosphatase has been implicated as marker in RD patients. It can offer diagnostic evidence by measurements of isoform of ALP activity derived from bone or liver.

The upward trend in glucose is an indirect confirmation of this (Kim, 2012; Kumar, 2016). A slight (15.8\%) increase in the level of thyroidstimulating hormone $(\mathrm{TSH})-1.93 \pm 0.11$ and $1.67 \pm 0.37 \mathrm{IU} / \mathrm{L}$, respectively (P>0.05), probably indicates a decrease in thyroid function glands inherent in the stress response and consistent with the literature data. 


\section{Conclusion}

In conclusion, this study demonstrated that serum vitamin D levels were significantly lower in TMJ patients. Calcium and vitamin D levels correlate inversely in TMJ patients. Vitamin D insufficiency is predominant in patients with TMJ compared to healthy subjects. Our research results confirm the important role of psycho-emotional disorders, pain, and hypertonicity of muscles, in particular chewing, in the pathogenesis of the development of TMJ pain dysfunction syndrome. Also, it indicates a change in the production of stress hormones (adrenaline and cortisol) that aggravate psycho-emotional disorders in patients and shift metabolic processes in the direction of catabolism, which is also indicated by an increase in ATP production. This suggests that the study of biochemical parameters of blood, in particular ATP, histamine, and hormones (adrenaline, cortisol, Total ALP) in blood serum can be used in the diagnosis of this pathology.

\section{References:}

1. Aliko, A., Ciancaglini, R., Alushi, A., Tafaj, A. \& Ruci, D. (2011). Temporomandibular Joint Involvement in Rheumatoid Arthritis, Systemic Lupus Erythematosus and Systemic Sclerosis.IntJ Oral Maxillofac Surg.CrossRef 40:704-709.

2. Antico, A., Tampoia, M., Tozzoli, R \& Bizzaro, N. (2012). Can Supplementation with Vitamin D Reduce the Risk or Modify the Course of Autoimmune Diseases? A systematic review of the literature. Autoimmunity Reviews. 12(2):127-136.

3. Adegboye, A. R., Christensen, L. B., Holm-Pedersen, P., Avlund, K., Boucher L., \& Heitmann, B. L. (2013); Intakes of Calcium, Vitamin D, and Dairy Servings and Dental Plaque in Older Danish adults. Nutrition Journal.12(61):1-5

4. Ahmed, N., Petersson, A. \& Catrina, A. I. (2015). Tumor Necrosis Factor Mediates Temporomandibular Joints Bone Tissue Resorption in Rheumatoid Arthritis. ActaOdontol Scand. 73(3):232-240.

5. Brini, M., Ottolini, D. \& Cali T. (2013) Carafoli E. Calcium in Health and Disease.Met. Ions Life Sci. 13:81-137.

6. Beto, J. A. (2015). The Role of Calcium in Human Aging. Clin. Nutr. Res. 4(1):1-8.

7. Boonstra, A., Barrat, F. J., Crain, C., Heath, V. L. \& Savelkoul, H. F. (2011). 1-Alpha, 25-Dihydroxyvitamin D3 Has a Direct Effect on Naive CD4(+) T Cells to Enhance the Development of Th2 Cells. J Immunol, 167:4974-4980.

8. Callhoff, J., Sieper, J., Weiss, A., Zink, A. \& Listing, J. (2015). Efficacy of TNFa Blockers in Patients with AnkylosingSpondylitis 
and Non-radiographic Axial Spondyloarthritis: A metaanalysis. AnnRheumDis.74:1241-1248.

9. Chervotok, A. (2009). Functional condicion of locomotor apparatus of patients with occlusion anomalies and deformity; author's abstract of dissertation of Candidate of Medical Science - St. Petersburg. p - 22.

10. Gelbard, A. (2017). Fibromyalgia Possibly the Result of Calcium Deficiency by Amos Gelbard. Human AnatJ.1(1):000103.

11. Grant, W. B. \& Boucher, B. J. (2010). Are Hill's Criteria for Causality Satisfied for Vitamin D and Periodontal Disease? Dermatoendocrinol.2:30-36.

12. Kim, Y. K., Kim, S. G. \& Kim, B. S. (2012). Analysis of the Cytokines Profiles of the Synovial Fluid in a Normal Temporomandibular joints: Preliminary Study. Craniomaxillofac. Surg. 40:337-341.

13. Kumar, V., Prakash, J., Gupta, V. \& Khan, M. Y. (2016). Antioxidant Enzymes in 14. Rheumatoid Arthritis. J Arthritis. 5:206:1-5.

14. Kudryavtseva, O. (2010). Peculiarities of diagnostics and treatment of patients with dentoalveolar anomalies, complicated with TMJ dysfunction: author's abstract of dissertation of Candidate of Medical Science. St. Petersburg. p - 17.

15. Leeuw, R. D. \& Klasser, G. D. (2013). American Academy of Orofacial Pain. Orofacial Pain: Guidelines for Assessment, Diagnosis, and Management. 5th ed. Chicago, Ill.: Quintessence Publ.

16. Maruotti, N. \& Cantatore, F. P. (2010). Vitamin D and the Immune System. J Rheumatol.37:491-495.

17. Marques, C. D., Dantas, A. T., Fragoso, T. S \& Duarte, A. L. (2010). The Importance of Vitamin D Levels in Autoimmune Diseases. Bras J Rheumatol.50(1):67-80.

18. Sipina L.V. (2003); Otsenka mineral' noy plotnosti kostnoy tkani i pokazateli kostnogo metabolizma $\mathrm{u}$ zhenshchin $\mathrm{s}$ diffuznym toksicheskim zobom: Avtoref. dis. ... kand. med. nauk. Moskva Vestegaard, P. \& Mosekilde, L. (2003). Thyroid. Vol. 13. P. 585-593.

19. Wong, Y. K. \& Chend, J. (2003). A case series of temporomandibular disorders treated with acupuncture, occlusal splint and point injection therapy, Acupunct. Med.: vol. 21, pp.138-149. 